\title{
Influence of Surface State on the Electrochemical Performance of Nickel-Based Cermet Electrodes during Steam Electrolysis
}

\author{
Basma Mewafy, $^{\dagger}$ Fotios Paloukis, $^{\dagger, \ddagger}$ Kalliopi M. Papazisi, ${ }^{\S}$ Stella P. Balomenou, ${ }^{\S}$ Wen Luo, ${ }^{\|, \triangle} \triangle$
}

Detre Teschner, ${ }^{\perp, \#}$ Olivier Joubert, ${ }^{\bigcirc}$ Annie Le Gal La Salle, ${ }^{\bigcirc}$ Dimitris K. Niakolas, ${ }^{\ddagger}$ and Spyridon Zafeiratos* ${ }^{*}+0$

\footnotetext{
${ }^{\dagger}$ Institut de Chimie et Procédés pour l'Energie, l’Environnement et la Santé UMR 7515 du CNRS-UdS, 25 Rue Becquerel, 67087 Strasbourg, France

${ }^{\ddagger}$ Foundation for Research and Technology, Institute of Chemical Engineering Sciences (FORTH/ICE-HT), Patras, GR-26504, Greece

${ }^{\S}$ Chemical Process and Energy Resources Institute/CERTH, sixth km Charilaou-Thermi Road, 57001 Thessaloniki, Greece

"Laboratory of Materials for Renewable Energy (LMER), École polytechnique fédérale de Lausanne (EPFL) Valais/Wallis, Rue de l'Industrie 17, CH-1951 Sion, Switzerland

${ }^{\perp}$ Departement of Inorganic Chemistry, Fritz-Haber-Institut der Max-Planck-Gesellschaft, Faradayweg 4-6, 14195 Berlin, Germany

\# Department of Heterogeneous Reactions, Max-Planck-Institut für Chemische Energiekonversion, Stiftstrasse 34-36, 45470

Mülheim a. d. Ruhr, Germany

OInstitut des Matériaux Jean Rouxel (IMN), Université de Nantes-CNRS, 2 Rue de La Houssinière, BP 32229, 44322 Nantes Cedex

3, France

$\triangle$ Empa Materials Science \& Technology, CH-8600 Dübendorf, Switzerland
}

Supporting Information

\begin{abstract}
Due to their fuel flexibility and high efficiency, solid oxide cells are a promising technology for sustainable energy production and storage. Nickel in combination with yttria-stabilized zirconia (YSZ) or gadolinium-doped ceria (GDC), forming Ni-YSZ or Ni-GDC cermets respectively, are the most widely adopted electrodes in solid oxide fuel cell fabrication. Currently, there is an increasing interest in cermet electrodes for hydrogen generation through high temperature steam electrolysis using solid oxide electrolysis cells (SOECs). However, durability remains a major issue for reliable operation of SOEC systems. A variety of processes accountable for permanent performance degradation of SOECs has been identified based on post-mortem cell analysis. Besides, transient/reversible degradation processes are typically examined by indirect methods, like impedance spectroscopy. The reason is that the application of material characterization techniques during SOEC operational conditions is challenging. In this work we provide a direct

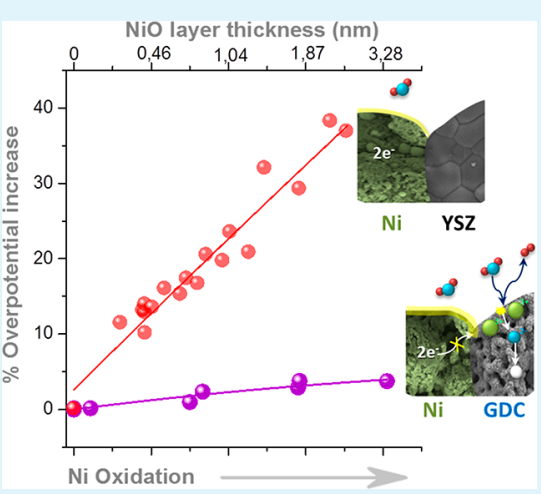
correlation between Ni-YSZ and Ni-GDC electrode surface oxidation states and their performance during steam electrolysis using operando experimental evidence provided by near ambient pressure X-ray photoelectron and near edge X-ray absorption fine structure spectroscopy. We show that nickel surface oxidation may induce significant performance degradation in Ni-YSZ cathodes while, on the contrary, having minor effects in Ni-GDC. Remarkably, we found that in the case of Ni-GDC electrodes, small modification of the GDC oxidation state can have an important impact on the electrolysis performance. The results highlight the crucial role of the cathode electrode surface oxidation state on the SOEC functionality and have potential implications for the design and operation strategies of more efficient and durable SOEC devices.
\end{abstract}

KEYWORDS: solid oxide electrochemical cells, steam electrolysis, cermet electrodes, doped ceria, near ambient pressure XPS, hydrogen production, deactivation

\section{INTRODUCTION}

Economically competitive hydrogen production using renewable and sustainable energy sources has been a long-standing goal in energy research. ${ }^{1}$ Among the various hydrogen production technologies, water electrolysis is particularly attractive since it can be used to store surplus renewable electricity created by wind or solar power sources. ${ }^{2,3}$ Solid oxide electrolysis cells (SOECs) are high temperature electro-

Received: April 18, 2019

Accepted: August 30, 2019

Published: August 30, 2019 
chemical devices in which water dissociates to hydrogen and oxygen under an applied potential. ${ }^{4}$ SOECs have great promise as a hydrogen production technology due to the fact that the demand in electrical energy is reduced with temperature, allowing high electrical-to-chemical energy conversion efficiencies. $^{5}$

Enhancing the efficiency of cathode materials in hydrogen production is recognized as one of the greatest challenges for SOEC technology. Currently, the most commonly used SOEC cathode is nickel mixed with yttria-stabilized zirconia (YSZ) ${ }^{6}$ due to its low cost, high electron conductivity, and thermal compatibility with other cell components. ${ }^{7}$ The role of $\mathrm{Ni}$ is mainly to provide the electrocatalytic sites and electronic conductivity, while YSZ conducts oxygen ions into the electrolyte and secures the mechanical stability of the electrode. ${ }^{8}$ Since YSZ exhibits negligible electrocatalytic activity toward water dissociation, the electrochemical reactions mainly occur in the vicinity of $\mathrm{Ni}$, YSZ, and fuel gas (three-phase boundaries, $3 \mathrm{~PB}){ }^{8}$ Therefore, replacing YSZ with a porous mixed ionic-electronic conductor (MIEC) material, which can also act as the electrocatalyst, has been considered as a method to increase the reaction sites of the electrodes. Doped ceria (DC) is probably the most suitable MIEC material for this purpose, since it combines good electronic and ionic conductivities with high electrochemical activity. ${ }^{9}$ The electrochemical reaction sites over DC are not limited in the $3 \mathrm{~PB}$ with nickel but are extended to the entire DC surface. ${ }^{9}$

A major drawback of SOECs devices is the insufficient longterm stability of their performance. ${ }^{10}$ Several processes have been held accountable for SOEC degradation. The best studied among them are morphological and microstructural modifications of the cathode electrode typically occurring after long-term operation. Characteristic examples are microstructure changes induced by sintering, reaction site blocking by impurities and electrode delamination. This kind of modifications are most of the time irreversible and can be displayed by post mortem microscopy images of the cell. ${ }^{11,12}$ In addition, changes of the chemical composition and the oxidation state of the cathode electrode have been also reported to induce deactivation. ${ }^{13}$ Oxidation of nickel to $\mathrm{NiO}$ or $\mathrm{Ni}(\mathrm{OH})_{2}$ may occur when the cell is operating under low $\mathrm{H}_{2}$ production and high steam concentration conditions, ${ }^{14}$ by air leaks in the fuel circulation system, or even after long-term operation. Extended nickel oxidation or bulk $\mathrm{NiO}$ formation has an evident macroscopic influence on the cell (e.g., micro cracks, coarsening, etc.), due to the large $\mathrm{Ni}-\mathrm{NiO}$ volume change. ${ }^{15}$ Moreover, under mild oxidative conditions an $\mathrm{NiO}$ layer can be formed on top of the $\mathrm{Ni}$ phase affecting the cell performance. ${ }^{13}$ This kind of degradation is usually reversible, and the performance is improved upon reduction of nickel, challenging its detection by post-mortem cell analysis. ${ }^{16}$ Much less is known about the chemical state of ceria in Ni-GDC electrodes, but since oxygen vacancies are considered as the electrochemically reactive sites, a mixed $\mathrm{Ce}^{3+} / \mathrm{Ce}^{4+}$ oxidation state is usually assumed. ${ }^{17}$ The electrochemical methods typically employed for in situ analysis of SOECs, for example impedance spectroscopy measurements, cannot provide analytical evidence about the oxidation state of each electrode components, therefore the correlation between the SOEC performance and the electrode chemical state remains elusive. $^{13,18}$
Recently significant efforts have been put forward to apply material characterization techniques to analyze SOEC electrodes under working conditions ${ }^{16,19-27}$ and ascertain with certainty the degradation paths of their performance. In our previous study of water electrolysis over $\mathrm{Ni}$ gadolinium doped ceria (Ni-GDC) it was shown by using operando surface sensitive spectroscopies that maintaining nickel in a partial oxidation state is not always detrimental for steam electrolysis. On the contrary under certain operating conditions, a coreshell morphology consisting of a surface $\mathrm{Ni}-\mathrm{CeO}_{1.5}$ skin and an interior $\mathrm{NiO}-\mathrm{CeO}_{2}$ backbone can be beneficial. ${ }^{16}$ Reduced ceria, in the form of $\mathrm{CeO}_{1.5}$ was also found to be very active for methane electro-oxidation in case of Ni-GDC in fuel cell operation. $^{28}$

In the present work we pursuit this effort and investigate SOEC cells with Ni-YSZ and Ni-GDC cathode electrodes using in situ synchrotron X-ray photoelectron and absorption spectroscopies under near ambient pressure conditions. We explore the influence of the cathode surface oxidation state on the electrochemical properties of the cell during steam electrolysis. Similar nickel surface oxidation is detected for $\mathrm{Ni}-\mathrm{YSZ}$ and Ni-GDC electrodes in steam electrolysis upon $\mathrm{O}_{2}$ introduction with widely different overpotential changes. On the other hand, we demonstrate that the surface oxidation state of GDC is critical for the SOEC performance, which ultimately can help toward new SOEC electrodes development strategies.

\section{EXPERIMENTAL SECTION}

2.1. Three-Electrode Cell Preparation and Characterization. Two types of electrolyte supported electrochemical cells, with different working, but identical counter and reference electrodes, were fabricated for this study. The NiO-YSZ (Fuel Cell Materials, 66:34 wt \%, 8-mol \% $\mathrm{Y}_{2} \mathrm{O}_{3}$-doped $\mathrm{ZrO}_{2}$ ) and $\mathrm{NiO}$-GDC (Marion Technologies, 65:35 wt \%, 10-mol \% $\mathrm{GdO}_{2}$-doped $\mathrm{CeO}_{2}$ ) working electrodes were applied using the screen printing technique directly on YSZ pellets (Kerafol GmbH, 8YSZ) of 150 and $300 \mu \mathrm{m}$ thickness, respectively. ${ }^{29,30}$ Subsequently, the NiO-YSZ and NiO-GDC half cells were fired at 1350 and $1150{ }^{\circ} \mathrm{C}$ respectively, which lead to porous cermet electrodes with a thickness of about $40 \mu \mathrm{m}$ for both cell types. Platinum was chosen for the reference and counter electrodes due to its known performance stability in oxidizing and reducing environments. ${ }^{31}$ The Pt counter electrode was painted using platinum paste (ESL, 542-DG) opposite to Ni-GDC or Ni-YSZ electrodes with similar symmetrical shape and surface area to them. The Pt reference electrode was on the same side as the counter electrode separated by a gap of about $3 \mathrm{~mm}$. The area ratio between counter and reference electrodes was approximately 5 to 1 . A reference symmetric cell composed exclusively of Pt electrodes was also fabricated and tested in order to address possible effects of oxygen addition to the reaction kinetics. Electrochemical experiments were also performed on commercial prefabricated $\mathrm{NiO}-\mathrm{YSZ} / / \mathrm{YSZ}$ and $\mathrm{NiO}-\mathrm{GDC} / / \mathrm{YSZ}$ half cells (Kerafol $\mathrm{GmbH}$, both $150 \mu \mathrm{m}$ YSZ) in a laboratory reactor $^{32}$ which could operate at conditions similar to those of the synchrotron experiments. The aim was twofold: first to confirm that the electrochemical response of the cells under the employed reaction conditions is a general characteristic of the cermet electrodes and to perform EIS characterization of the cells without the time restrictions applied in synchrotron-based experiments. These experiments confirmed the reproducibility of the electrochemical performance, while the EIS spectra and the scanning electron microscopy (SEM) micrographs presented in this work were recorded using these cells. The surface morphology was inspected by SEM using a Zeiss GeminiSEM 500 microscope. Energy-dispersive X-ray spectroscopy (EDXS) mapping was combined with the SEM images to resolve the different elements on the surface of the electrodes.

2.2. Synchrotron Based Experiments. In situ near ambient pressure X-ray photoelectron and near edge absorption fine structure 
a) Overpotential \& gas phase $\mathrm{O}_{2} \quad$ Working electrode: Ni-YSZ

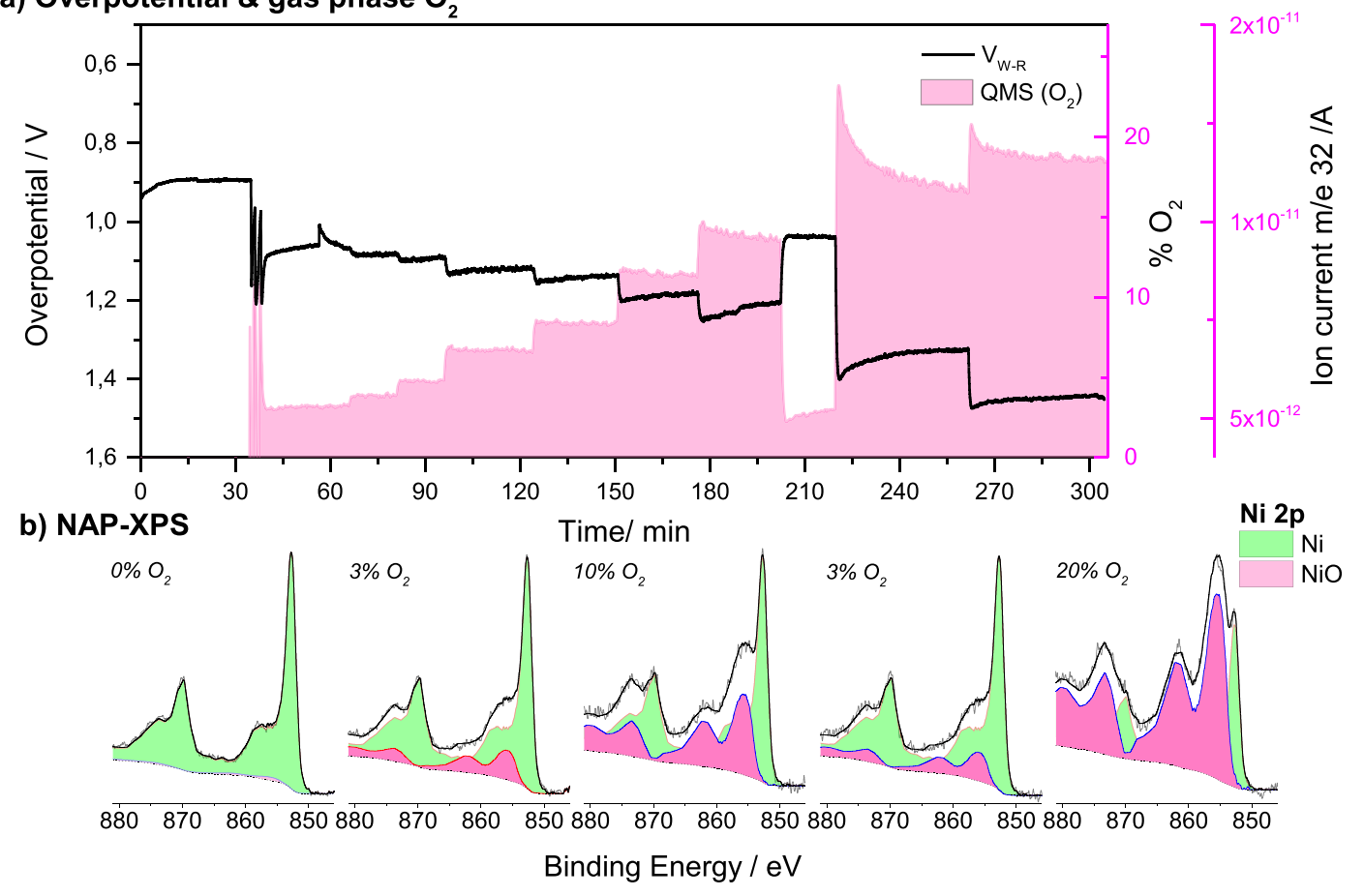

Figure 1. (a) Time evolution of the Ni-YSZ cathode overpotential (black line) and the on line mass spectrometer signal of oxygen (pink line) measured at constant current of $-100 \mathrm{~mA} / \mathrm{cm}^{2}$ while different concentrations of $\mathrm{O}_{2}$ were introduced in the $\mathrm{H}_{2} \mathrm{O} / \mathrm{H}_{2}$ feed. The temperature was kept constant at $640{ }^{\circ} \mathrm{C}$. (b) Ni 2p NAP-XPS spectra recorded during characteristic moments of the conditions appearing in part a. Two Ni $2 p$ components were used to fit the spectra corresponding to metallic $\mathrm{Ni}$ (green) and oxidized $\mathrm{NiO}$ (pink).

spectroscopies (NAPXPS and NEXAFS, respectively) were performed at ISISS beamline at BESSY synchrotron radiation facility at the Helmholtz-Zentrum-Berlin. ${ }^{33}$ Cells with ca. $0.3 \mathrm{~cm}^{2}$ geometric surface area were mounted between two stainless steel clamps; the one at the top with a $4 \mathrm{~mm}$ diameter slit and the other at the bottom was separated in two stainless steel plates for the reference and the counter electrodes, respectively. The stainless steel clamps were also used as the current collectors, and they were connected through two ball pressed screws with the potentiostat. Heating was performed from the rear side using an IR-laser, while the temperature was monitored at the center of the working electrode by a pyrometer. The gas flow into the reaction cell was controlled by mass flow controllers while the gas phase was monitored by an online quadrupole mass spectrometer (QMS). Electrical potentials were applied between the working and the counter electrodes and the current flow was measured using a computer controlled VersaSTAT3-200 potentiostat/galvanostat (Princeton Applied Research). The working electrode was grounded and the bias voltage was applied on the counter electrode. Initial annealing of the cells in 0.5 mbar $\mathrm{O}_{2}$ was used prior to spectroscopic measurements to eliminate residual carbon from the surface. After this procedure the $\mathrm{C} 1 \mathrm{~s}$ signal was within the noise level during all experiments. Unless otherwise stated, the total pressure during the experiments was kept constant at 0.5 mbar. No significant electrostatic charging was observed under the employed temperature and pressure conditions. The average thickness of the $\mathrm{NiO}$ overlayer formed over the metallic nickel particles core was determined by the $\mathrm{Ni} 2 \mathrm{p}$ photoelectron peak intensity using the simplified formula described in ref 34 .

2.3. Description of the in situ Electrochemical Experiments with $\mathrm{O}_{2}$ Introduction in the $\mathrm{H}_{2} \mathrm{O} / \mathrm{H}_{2}$ Feed. The degradation tests in the presence of $\mathrm{O}_{2}$ were performed following a similar experimental routine for both cell types. The electrodes were initially reduced in $\mathrm{H}_{2}$ at $640{ }^{\circ} \mathrm{C}$ and then the gas feed switched to $75 \% \mathrm{H}_{2} \mathrm{O} / 25 \% \mathrm{H}_{2}$ and a constant current between the cathode and the anode at $640{ }^{\circ} \mathrm{C}$ (electrolysis conditions) was applied. Gradually and without changing the operation conditions otherwise, different amounts of $\mathrm{O}_{2}$ (from 3\% up to $17 \%$ ) were introduced in the $\mathrm{H}_{2} \mathrm{O} / \mathrm{H}_{2}$ mixture keeping the overall pressure constant at 0.5 mbar. The degradation of the cell was evaluated by measuring the potential change between working and reference electrodes. This potential is corrected for the ohmic drop (given by the high frequency cut off in the impedance spectra measured at identical conditions) and is presented as the overpotential. The electrochemical impedance spectra (EIS) were measured in galvanostatic conditions $(20 \mathrm{~mA})$ with frequency range from $10 \mathrm{mHZ}$ to $100 \mathrm{kHz}$ (for Ni-GDC electrode) or $500 \mathrm{kHz}$ (for $\mathrm{Ni}$-YSZ electrode) and a signal amplitude of $2 \mathrm{~mA}$. To compare the cells with Ni-YSZ and Ni-GDC electrodes the percent increase of the potential as compared to its initial values (before $\mathrm{O}_{2}$ introduction) was calculated. Please note that prior to the introduction of $\mathrm{O}_{2}$ the sample was kept to the same conditions for about $1 \mathrm{~h}$ in order to stabilize the potential.

\section{RESULTS}

3.1. Effect of Nickel Oxidation on the Cell Performance. The reduction kinetics of nickel oxide $(\mathrm{NiO})$ in $\mathrm{H}_{2}$ are extremely fast, especially at high temperature; therefore, $\mathrm{NiO}$ reduces to metal within few seconds in the $\mathrm{H}_{2} \mathrm{O} / \mathrm{H}_{2}$ mixture. ${ }^{16,29,35,36}$ In order to investigate the effect of nickel oxidation during steam electrolysis, $\mathrm{O}_{2}$ was co-introduced with $\mathrm{H}_{2} \mathrm{O} / \mathrm{H}_{2}$ at constant current operation conditions. Nickel oxidation is expected to be homogeneous into the whole cermet volume, since at intermediate temperatures $\left(<700{ }^{\circ} \mathrm{C}\right)$ the oxidation process is not limited by the $\mathrm{O}_{2}$ gas diffusion. ${ }^{37}$ Accordingly, the NAP-XPS spectra recorded on the surface of the cathode are representative also for the chemical state at the interface with YSZ electrolyte. Below we describe the experiments performed at two cells utilizing $\mathrm{Ni}-\mathrm{YSZ}$ and $\mathrm{Ni}$ GDC electrodes, respectively.

3.1.1. Ni-YSZ Cathode. Figure 1a shows the evolution of the $\mathrm{Ni}-\mathrm{YSZ} / \mathrm{YSZ} / \mathrm{Pt}$ cell overpotential and the QMS signal of $m / e$ 
a) Overpotential \& gas phase $\mathrm{O}_{2} \quad$ Working electrode: $\mathrm{Ni}$-GDC

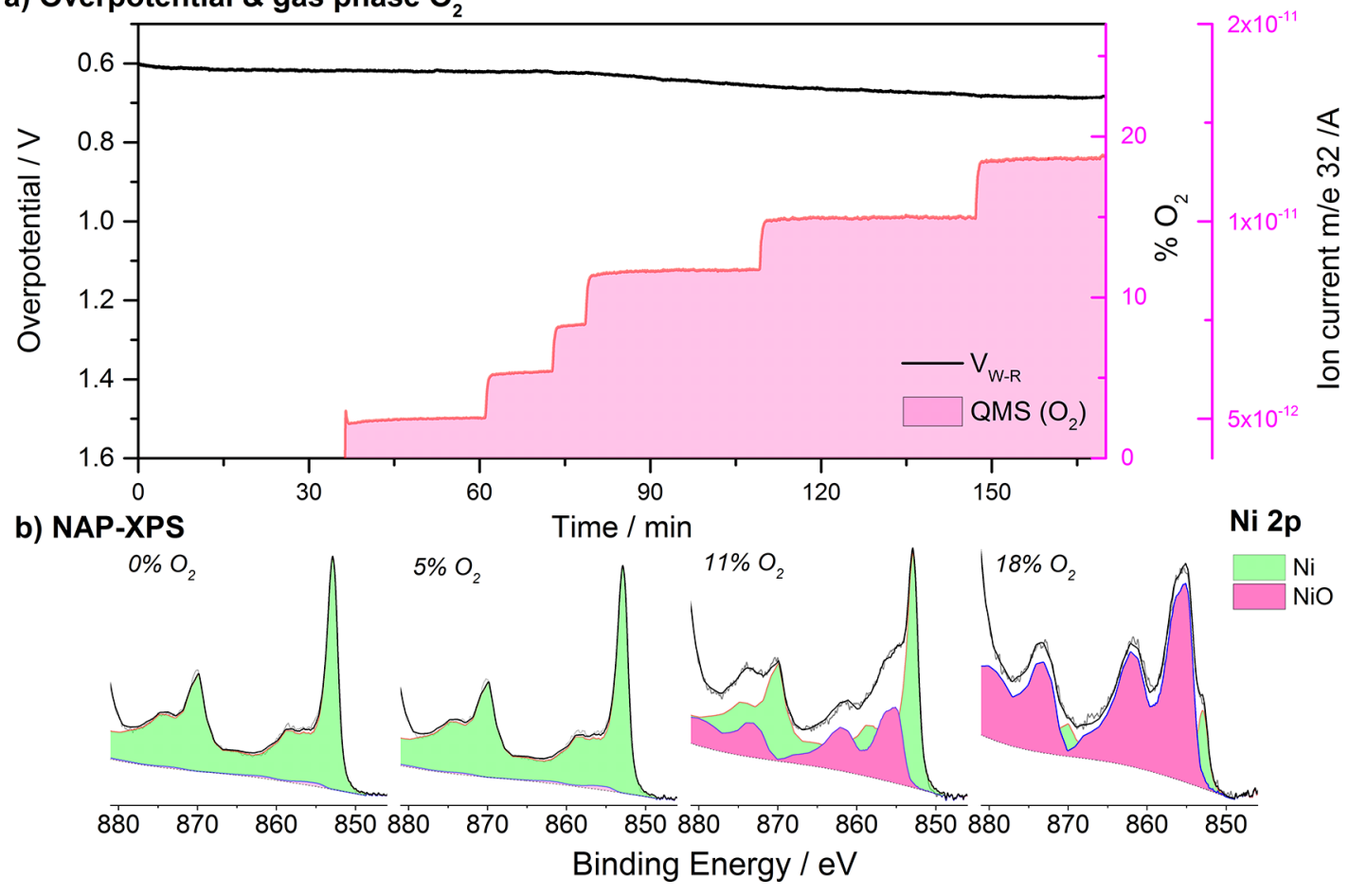

Figure 2. (a) Time evolution of the Ni-GDC cathode overpotential (black line) and the online mass spectrometer signal of oxygen (pink line) measured at constant current of $-100 \mathrm{~mA} / \mathrm{cm}^{2}$ while different concentrations of $\mathrm{O}_{2}$ were introduced in the $\mathrm{H}_{2} \mathrm{O} / \mathrm{H}_{2}$ feed. The temperature was kept constant at $640{ }^{\circ} \mathrm{C}$. (b) Ni 2p NAP-XPS spectra recorded during characteristic moments of the conditions appearing in part a. Two Ni $2 p$ components were used to fit the spectra corresponding to metallic $\mathrm{Ni}$ (green) and oxidized $\mathrm{NiO}$ (pink).

32 (oxygen) as a function of time. A constant current of -100 $\mathrm{mA} / \mathrm{cm}^{2}$ was applied at the Ni-YSZ cathode while the $3 / 1$ $\mathrm{H}_{2} \mathrm{O} / \mathrm{H}_{2}$ mixture composition and the overall pressure were maintained throughout the experiment. Initially under $\mathrm{H}_{2} \mathrm{O}$ / $\mathrm{H}_{2}$ flow the overpotential is stabilized at ca. $0.9 \mathrm{~V}$ after a short transition period of about $15 \mathrm{~min}$. The introduction of $\mathrm{O}_{2}$ in the $\mathrm{H}_{2} \mathrm{O} / \mathrm{H}_{2}$ feed induces significant cell deactivation as indicated by the gradual increase of the overpotential. A clear trend between the increase of $\mathrm{O}_{2}$ partial pressure and the overpotential can be established, while the process is reversible and the potential recovers when $\mathrm{O}_{2}$ was switched back to lower pressure (around $210 \mathrm{~min}$ in Figure 1a). Characteristic Ni 2p NAP-XPS spectra collected at various stages of the experiment are shown in Figure 1b. Based on earlier photoemission studies the Ni $2 \mathrm{p}$ peak can be deconvoluted into two components; one sharp $\mathrm{Ni} 2 \mathrm{p}_{3 / 2}$ peak around $853 \mathrm{eV}$ which corresponds to metallic $\mathrm{Ni}$, and a broader $\mathrm{Ni} 2 \mathrm{p}_{3 / 2}$ feature at $856 \mathrm{eV}$ associated with oxidized $\mathrm{Ni}^{38-40}$ The spectrum recorded in the $\mathrm{H}_{2} \mathrm{O} / \mathrm{H}_{2}$ is exclusively due to metallic $\mathrm{Ni}$, while upon co-feeding of $\mathrm{O}_{2}$ the characteristic peak of oxidized $\mathrm{Ni}$ appears. The contribution of the $\mathrm{NiO}$-related component to the overall $\mathrm{Ni}$ $2 p$ spectrum increases with the $\mathrm{O}_{2}$ partial pressure. Please note that the $\mathrm{Ni} 2 \mathrm{p}_{3 / 2}$ peak at $853 \mathrm{eV}$ does not exhibit the distinctive shoulder at about $854.5 \mathrm{eV}$ typically observed of stoichiometric $\mathrm{NiO}^{41}$ This fact suggests that the structural and electronic properties of oxidized Ni differ from those of bulk $\mathrm{NiO}$ material. However, for simplicity we will refer to the oxidized $\mathrm{Ni}$ as $\mathrm{NiO}$.

3.1.2. Ni-GDC Cathode. The influence of nickel oxidation on the Ni-GDC cathode performance was examined on a NiGDC/YSZ/Pt cell following a procedure similar to Ni-YSZ. The overpotential and $m / e$ 32 QMS signal recorded at -100
$\mathrm{mA} / \mathrm{cm}^{2}$ and at various $\mathrm{O}_{2}$ concentrations in the $\mathrm{H}_{2} \mathrm{O} / \mathrm{H}_{2}$ mixture are shown in Figure 2a. Surprisingly, while the increase of the $\mathrm{O}_{2}$ partial pressure in the $\mathrm{H}_{2} \mathrm{O} / \mathrm{H}_{2}$ feed is manifested by the online QMS signal, the overpotential change is minor in comparison to the Ni-YSZ electrode. As shown by the real time NAP-XPS spectra in Figure $2 \mathrm{~b}$, the evolution of $\mathrm{NiO}$ component in the $\mathrm{Ni} 2 \mathrm{p}$ peak follows the $\mathrm{O}_{2}$ partial pressure confirming that nickel is gradually oxidized by gas phase $\mathrm{O}_{2}$, similar to Ni-YSZ. Thus, surface $\mathrm{NiO}$ formation has only a modest effect on the Ni-GDC cell overpotential as compared to Ni-YSZ cell.

Comparison of the $\mathrm{Ni} 2 \mathrm{p}$ spectra of the two electrodes (Figure $1 \mathrm{~b}$ and $2 \mathrm{~b}$ ) shows that nickel oxidation starts at lower $\mathrm{O}_{2}$ concentration for Ni-YSZ as compared to Ni-GDC. This divergence might be attributed to differences in the microstructure and/or in the ability of nickel to chemisorb and dissociate oxygen species from the gas phase, which are known factors affecting nickel oxidation. ${ }^{42-44}$ One can argue that the preparation and the pretreatment of the two electrodes affect differently the nickel microstructure and surface sites and in turn, influences the oxidation kinetics. However, the observed differences are restricted at the initial oxidation stages, while at higher $\mathrm{O}_{2}$ concentration nickel oxidation is similar for both electrodes.

3.1.3. Stability of Pt Electrodes. In order to ensure the chemical stability of $\mathrm{Pt}$ electrodes in the presence of $\mathrm{O}_{2}$, in a separate experiment the Pt $4 \mathrm{f}$ spectra of the counter electrode under similar conditions were measured by NAP-XPS (see Supporting Information (SI) 1). These experiments show that $\mathrm{Pt}$ is metallic under all tested conditions and its oxidation state is not affected by the applied current or by gas phase $\mathrm{O}_{2}$. Apart from the chemical stability of $\mathrm{Pt}$ we also tested the influence of 
$\mathrm{O}_{2}$ addition on the electrochemical reaction kinetics, considering that $\mathrm{O}_{2}$ is the product of oxygen ion oxidation at the anode and by introducing it in the feed we change the reaction equilibrium. For this purpose we prepared symmetric electrochemical cells where Ni-YSZ was replaced by a $\mathrm{Pt}$ electrode. Since, as shown in SI 1, the Pt oxidation state is not influenced by the introduction of $\mathrm{O}_{2}$ in the feed, this experiment can indicate a possible influence of the reaction kinetics on the overpotential on chemically stable electrodes. In SI 2, we show that the addition of $\mathrm{O}_{2}$ in the $\mathrm{H}_{2} \mathrm{O} / \mathrm{H}_{2}$ feed does not have an evident effect on the measured overpotential when a symmetric Pt cell is used, and accordingly, its effect on the electrochemical reaction kinetics should be neglected. Therefore, since $\mathrm{O}_{2}$ addition has no measurable effects on the chemical state of $\mathrm{Pt}$ counter/reference electrodes and the reaction kinetics, the overpotential increase observed upon introduction of $\mathrm{O}_{2}$ should be correlated to the distinct modifications observed on the cathode chemical state.

3.2. Effect of the Oxidation State of the Ceramic Part on the Cell Performance. Having shown that the surface oxidation state of nickel has distinctly different impact on $\mathrm{Ni}$ YSZ and Ni-GDC electrodes, we explore now the effect of the chemical state of the ceramic part. In the case of Ni-YSZ, the Zr 3d core level peak (SI 3) is characteristic of doped YSZ. ${ }^{29,45}$ The spectrum shifts to higher binding energy under polarization as compared to open circuit; however, the peak shape is not affected by the applied current or the presence of $\mathrm{O}_{2}$. The observed binding energy shift is induced by changes of the overpotential across the Ni/YSZ electrochemical interface as has been demonstrated in previous photoemission studies. ${ }^{46,47}$ The stable $\mathrm{Zr} 3 \mathrm{~d}$ peak shape is in agreement with reports suggesting that the chemical state of YSZ is not influenced by the applied current or the presence of $\mathrm{O}_{2}{ }^{29}$ The high thermal and chemical stability of the YSZ surface support the hypothesis that the performance of the cell with Ni-YSZ cathode is primarily related to the oxidation state of nickel.

In the case of the Ni-GDC electrode the analysis of the Ce $3 \mathrm{~d}$ spectrum prior to current application shows that GDC contains contributions of both $\mathrm{Ce}^{3+}$ and $\mathrm{Ce}^{4+}$ cations (Figure 3 ) in accordance with several previous reports of ceria in $\mathrm{H}_{2} \mathrm{O}$ / $\mathrm{H}_{2}$ mixtures. ${ }^{16,25,40,48,49}$ The ratio between $\mathrm{Ce}^{3+}$ and $\mathrm{Ce}^{4+}$ does not change appreciably with the applied current, yet upon $\mathrm{O}_{2}$ introduction, a small, but consistent, increase of the $\mathrm{Ce}^{4+}$ component is observed in the Ce $3 \mathrm{~d}$ spectrum of Figure 3. This can be clearly seen also in the Ce $\mathrm{M}_{5}$-edge NEXAFS spectrum shown in SI 4. Although the ceria oxidation state in the presence of $\mathrm{O}_{2}$ is much less influenced as compared to nickel, according to previous findings its impact on the electrode activity might be substantial. ${ }^{28,48,50}$

However, given that the introduction of $\mathrm{O}_{2}$ in the $\mathrm{H}_{2} \mathrm{O} / \mathrm{H}_{2}$ mixture influences the chemical state of both nickel and GDC areas, the impact of the GDC oxidation state cannot be safely evaluated from the above presented results. In order to maintain nickel in a stable oxidation state while varying that of GDC, we take advantage of the much slower kinetics of ceria reduction in $\mathrm{H}_{2} \mathrm{O} / \mathrm{H}_{2}$ mixture as compared to nickel oxide. ${ }^{40}$ In particular, a preoxidized Ni-GDC electrode was exposed to $\mathrm{H}_{2} \mathrm{O} / \mathrm{H}_{2}$ atmosphere and almost instantly an electrical current of $-100 \mathrm{~mA} / \mathrm{cm}^{2}$ was applied while Ce $3 \mathrm{~d}$ spectra were collected in short time periods (ca. every $10 \mathrm{~min}$ ). Figure $4 \mathrm{a}$ presents the evolution of the overpotential as a function of time recorded in this experiment. It is clear that within the first $40 \mathrm{~min}$ the overpotential decreased around $200 \mathrm{mV}$, while a

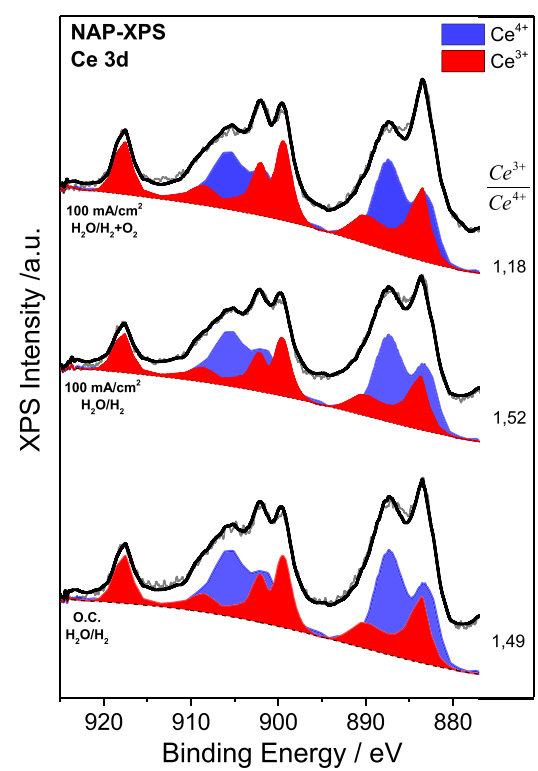

Figure 3. NAP-XPS Ce $3 \mathrm{~d}$ spectra measured on the Ni-GDC cathode electrode in $0.5 \mathrm{mbar} \mathrm{H}_{2} \mathrm{O} / \mathrm{H}_{2}$ at $640{ }^{\circ} \mathrm{C}$ (from bottom to the top) at open circuit, application of $-100 \mathrm{~mA} / \mathrm{cm}^{2}$ and application of -100 $\mathrm{mA} / \mathrm{cm}^{2}$ and cofeed of $\mathrm{O}_{2}$. Two Ce $3 \mathrm{~d}$ components were used to fit the spectra corresponding to $\mathrm{Ce}^{3+}$ (blue) and $\mathrm{Ce}^{4+}$ (red) oxidation states.

plateau of about $750 \mathrm{mV}$ was reached after $1 \mathrm{~h}$. The $\mathrm{Ni} 2 \mathrm{p}_{3 / 2}$ spectrum recorded in $\mathrm{H}_{2} \mathrm{O} / \mathrm{H}_{2}$ mixture prior to current application shows a characteristic peak of metallic Ni (Figure $4 \mathrm{~b})$. This confirms that $\mathrm{NiO}$ which is formed during the preoxidation step is reduced almost instantly to the metallic state upon introduction of $\mathrm{H}_{2} \mathrm{O} / \mathrm{H}_{2}$. On the other hand, the Ce $3 \mathrm{~d}$ peak shape is modified (Figure $4 \mathrm{~b}$ ), which according to the fit process is due to the relative increase of the $\mathrm{Ce}^{3+}$ species (for more details please refer to SI 5). The noticeable agreement between the formation of $\mathrm{Ce}^{3+}$ and the improvement of the cell performance becomes evident in Figure 4a, where the evolution of ceria oxidation state is compared with the cell overpotential.

Despite the fact that in the above-described dynamic experiment the oxidation state of $\mathrm{Ni}$ was constant, the $\mathrm{Ni}$ $2 \mathrm{p} / \mathrm{Ce} 3 \mathrm{~d}$ peak area ratio (SI 6) decreased with time. This indicates losses of nickel surface area ${ }^{16,40}$ which can potentially influence the Ni-GDC electrode performance. The two primary factors contributing to the changes of the $\mathrm{Ni} 2 \mathrm{p} / \mathrm{Ce}$ $3 \mathrm{~d}$ peak area ratio are the modification in the volume of nickel and ceria particles and the mutual surface segregation between them, as described elsewhere. ${ }^{16,28}$ In order to stabilize the electrode morphology the cell was annealed at $810^{\circ} \mathrm{C}$ in $\mathrm{H}_{2} \mathrm{O}$ / $\mathrm{H}_{2}$ for about $6 \mathrm{~h}$. This treatment decreased the $\mathrm{Ni} / \mathrm{Ce}$ ratio by about $40 \%$ (from 5.9 to 3.7); however, it stabilizes it during the following tests. High temperature pretreatment in $\mathrm{H}_{2} / \mathrm{H}_{2} \mathrm{O}$ induces also a significant reduction of GDC as evident by the increase of $\mathrm{Ce}^{3+}$ to $\mathrm{Ce}^{4+}$ ratio from 0.57 to 1.54 . Figure 5 correlates the ceria oxidation state and the cell overpotential for practically stable electrode morphology (as shown by the almost fixed $\mathrm{Ni} / \mathrm{Ce}$ ratio). The different ceria oxidation states were obtained either by subjecting the sample in $\mathrm{O}_{2}$ prior to the electrochemical reaction or by in situ transformation of GDC during electrochemical testing (the conditions of each measuring point are included in Figure 5 and explained in SI 7). In all cases the cell was measured under identical 
a) $\mathrm{H}_{2} \mathrm{O}: \mathrm{H}_{2} 3: 1630^{\circ} \mathrm{C} 100 \mathrm{mAcm}^{-2}$

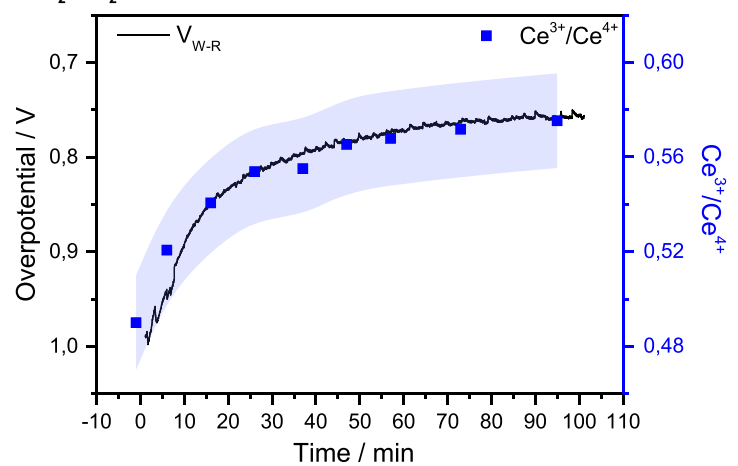

b) $\mathrm{Ni} 2 \mathrm{p}_{3 / 2} \& \mathrm{Ce} 3 \mathrm{~d}$

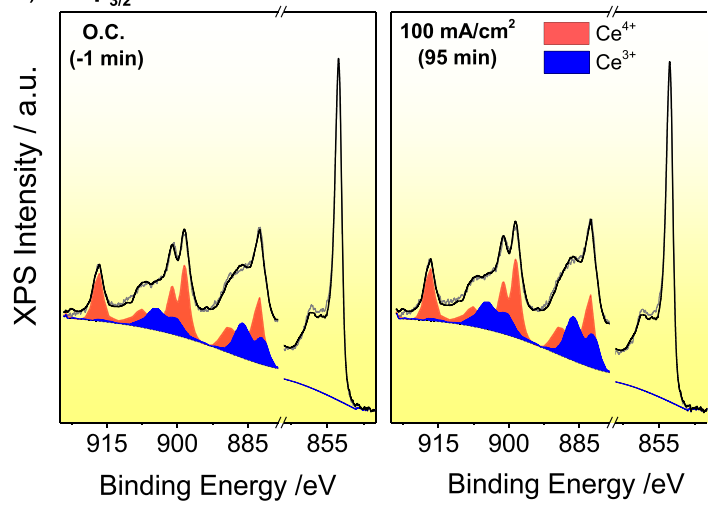

Figure 4. Reduction of Ni-GDC electrode (a) time evolution of the $\mathrm{Ni}-\mathrm{GDC} / \mathrm{YSZ} / \mathrm{Pt}$ cell overpotential (solid black line) and the evolution of $\mathrm{Ce}^{3+} / \mathrm{Ce}^{4+}$ components ratio (blue points) as derived by the analysis of the corresponding NAP-XPS Ce $3 \mathrm{~d}$ spectra. Measurements were performed on preoxidized Ni-GDC cathodes in 3:1 $\mathrm{H}_{2} \mathrm{O} / \mathrm{H}_{2}$ gas mixture at $640{ }^{\circ} \mathrm{C}$ and at constant current of -100 $\mathrm{mA} / \mathrm{cm}^{2}$. The blue color background represents the uncertainty in the calculation of the $\mathrm{Ce}^{3+} / \mathrm{Ce}^{4+}$ ratio mainly related to the deconvolution procedure. (b) Characteristic Ni $2 \mathrm{p}_{3 / 2}$ and Ce $3 \mathrm{~d}$ NAP-XPS spectra in $\mathrm{H}_{2} \mathrm{O} / \mathrm{H}_{2}$ before and after current application. Two Ce $3 \mathrm{~d}$ components were used to fit the spectra corresponding to $\mathrm{Ce}^{3+}$ (blue) and $\mathrm{Ce}^{4+}$ (red) oxidation states of ceria. electrolysis conditions (in $\mathrm{H}_{2} \mathrm{O} / \mathrm{H}_{2}$ mixture at $-100 \mathrm{~mA} / \mathrm{cm}^{2}$ ). In this way we were able to monitor the effect of ceria oxidation state over a morphologically stable Ni-GDC electrode. A monotonic inverse correlation of the ceria oxidation state with the overpotential is observed with a significantly higher $\mathrm{Ce}^{3+} / \mathrm{Ce}^{4+}$ ratio (more reduced ceria) to be favorable to lower electrolysis overpotentials.

3.3. Morphology of the Tested Cells. The SEM micrographs recorded on the surface of the two electrodes after the oxidation tests are presented in Figure 6 and in SI 8. Both electrode types show a typical cermet structure with high porosity and distinctive grains of nickel and ceramic phases, in the size range of $1-5 \mu \mathrm{m}$. The nickel and ceramic parts of the electrode are distinguished by the EDX analysis and can be seen in the higher magnification images. The nickel particles for both electrodes appear rough and also include some irregular-shaped pores on their surface. Although nickel particles look similar in both electrode types, the morphology of the ceramic parts differs. The YSZ areas (Figure 6a) do not contain pores but have clearly distinguished boundaries between the sintered YSZ grains. On the other hand the GDC (Figure $6 \mathrm{~b}$ ) is evidently more porous as compared to YSZ, indicating that GDC areas of the electrode are composed by a network of smaller GDC particles. Therefore, one can argue that even if nickel and ceramic weight percent composition is similar in the two electrodes, the surface area of GDC should be considerably higher than that of YSZ due to the porous morphology of the former. Consequently, the higher population of electrochemically active sites is expected for Ni-GDC as compared to the Ni-YSZ electrode. Likely, this might justify lower overpotential of Ni-GDC cell as compared to Ni-YSZ for the same current densities in Figures 1 and 2. Nevertheless, comparison of the SEM images of Ni-YSZ and $\mathrm{Ni}$-GDC spent electrodes reveals no discernible morphological differences, at least in the nickel areas. Accordingly the differences in the electrochemical response of the two electrodes observed upon nickel oxidation cannot be justified by analogous differences in the surface structure, leaving the

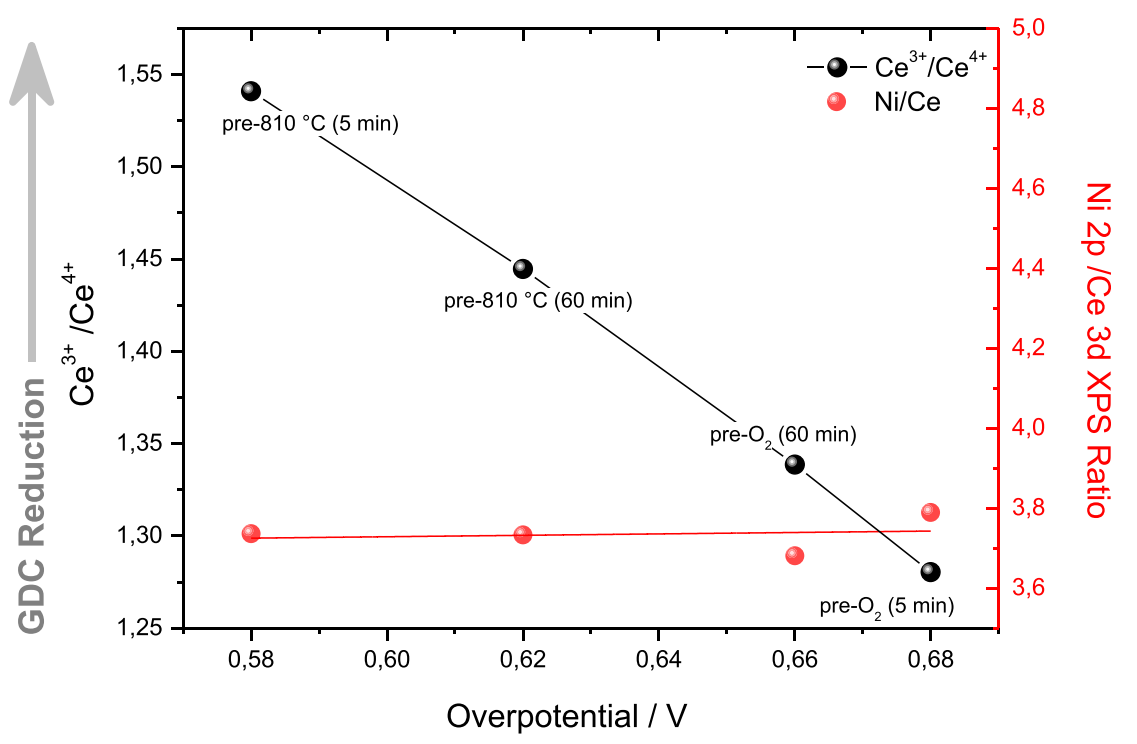

Figure 5. Correlation of GDC oxidation state as expressed by the $\mathrm{Ce}^{3+} / \mathrm{Ce}^{4+}$ ratio and the corresponding Ni $2 \mathrm{p} / \mathrm{Ce} 3 \mathrm{~d}$ peak area ratio obtained by the analysis of Ce $3 \mathrm{~d}$ and Ni 2p NAP XPS peak as a function of the overpotential. The measurements were performed on Ni-GDC cathodes in 3:1 $\mathrm{H}_{2} \mathrm{O} / \mathrm{H}_{2}$ gas mixture at $640{ }^{\circ} \mathrm{C}$ and at constant $-100 \mathrm{~mA} / \mathrm{cm}^{2}$ current after cell pretreatment at the indicated conditions. 


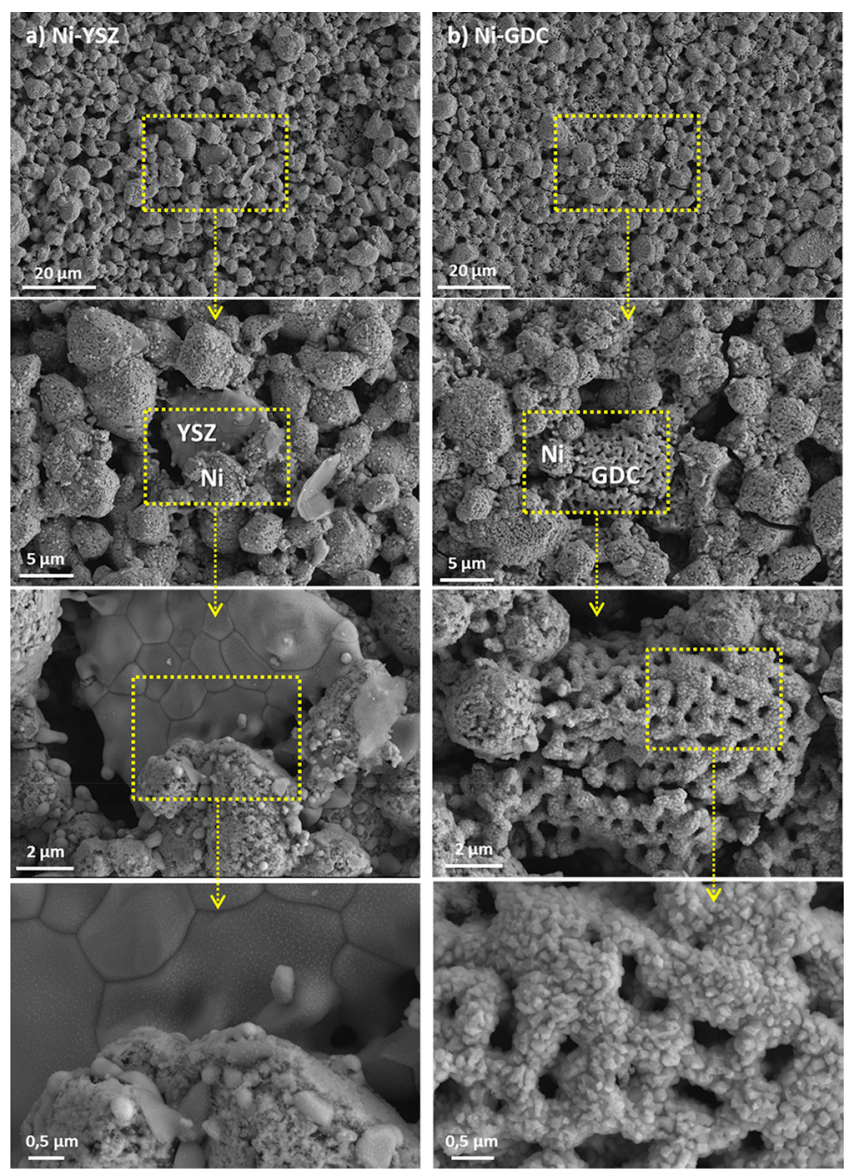

Figure 6. Characteristic SEM micrographs of the surface of (a) NiYSZ and (b) Ni-GDC electrodes recorded after the oxidation tests. changes of the surface oxidation state as the most plausible explanation of the electrochemical performance.

3.4. Comparison of Ni-YSZ and Ni-GDC Electrochemical Performance. Comparison of Figures 1 and 2 suggests that $\mathrm{Ni}-\mathrm{YSZ}$ and $\mathrm{Ni}-\mathrm{GDC}$ electrodes respond differently to surface $\mathrm{NiO}$ formation. The effect of nickel oxidation on the overpotential of the two electrodes is directly compared in Figure $7 \mathrm{a}$, showing the percent increase of the overpotential as a function of the nickel oxidation state and the average $\mathrm{NiO}$ film thickness. The latter was calculated by the analysis of the $\mathrm{Ni} 2 \mathrm{p}$ spectra recorded in the course of the experiment. ${ }^{34} \mathrm{~A}$ monotonic increase of the overpotential with nickel oxidation is observed for both electrodes, but in the case of Ni-YSZ, the overpotential increase is considerably higher. This is a quite substantial difference which indicates that the role of nickel during water electrolysis might vary in the two cermet electrodes.

Electrochemical impedance spectroscopy (EIS) is often used in order to distinguish the contribution of different cell components or processes to the total electrode impedance. The EIS spectra of Ni-YSZ and Ni-GDC electrodes measured in $\mathrm{H}_{2} \mathrm{O} / \mathrm{H}_{2}(3 / 1)$ and $\mathrm{H}_{2} \mathrm{O} / \mathrm{H}_{2} / \mathrm{O}_{2}(3 / 1 / 1)$ feeds are compared in the Nyquist plots given in Figure $7 \mathrm{~b}$ and $\mathrm{c}$, respectively. The Nyquist plots of both electrodes consist of two main semi circles. The depressed high frequencies arc is attributed to the electrolyte (YSZ) bulk impedance, while the low frequency arc corresponds to processes taking place at the cathode, typical for low temperature cell operation. ${ }^{27}$ It can be seen that the EIS spectra of Ni-YSZ and Ni-GDC electrode cells in $\mathrm{H}_{2} \mathrm{O} / \mathrm{H}_{2}$ are different, while they also respond differently when $20 \%$ of $\mathrm{O}_{2}$ is added into the $\mathrm{H}_{2} \mathrm{O} / \mathrm{H}_{2}$ flow. Commonly, in the Nyquist plot the high frequency intercept of the real axis represents the ohmic resistance $\left(R_{\mathrm{Ohm}}\right)$, while the
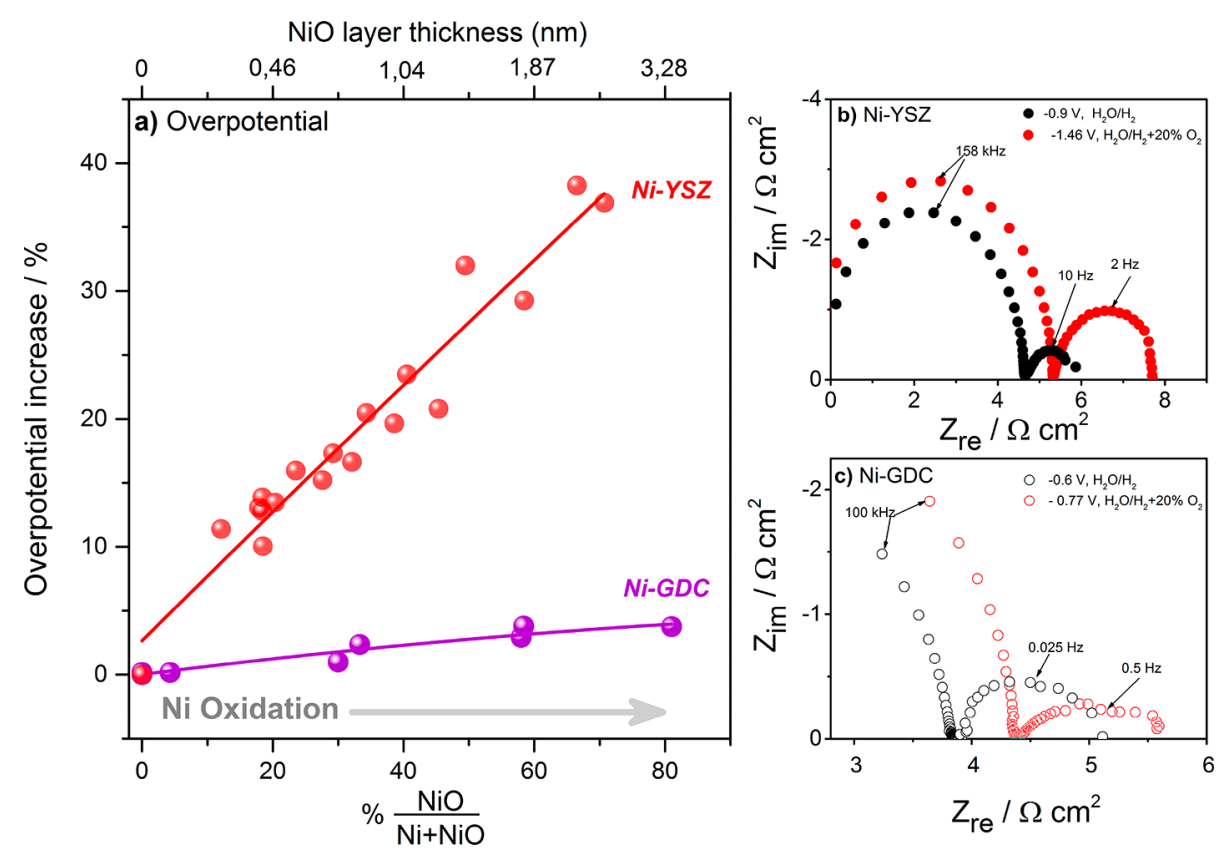

Figure 7. (a) Comparison of the percent overpotential increase of cells with Ni-YSZ and Ni-GDC cathode electrodes as a function of the relative amount of $\mathrm{NiO}$ and the average $\mathrm{NiO}$ film thickness (derived by the analysis of the corresponding NAP-XPS Ni $2 \mathrm{p}$ spectra recorded using $1320 \mathrm{eV}$ photon energy). Measurements were performed at $640{ }^{\circ} \mathrm{C}$ and at constant current of $-100 \mathrm{~mA} / \mathrm{cm}^{2}$ while different concentrations of $\mathrm{O}_{2}$ were introduced in the $\mathrm{H}_{2} \mathrm{O} / \mathrm{H}_{2}$ feed. Impedance spectra presented in Nyquist form, obtained under constant applied current of $-100 \mathrm{~mA} \mathrm{~cm}{ }^{-2}$ at 640 ${ }^{\circ} \mathrm{C}$ in $\mathrm{H}_{2} \mathrm{O} / \mathrm{H}_{2}(3 / 1)$ and $\mathrm{H}_{2} \mathrm{O} / \mathrm{H}_{2} / \mathrm{O}_{2}(3 / 1 / 1)$ at total pressure of 0.5 mbar from two electrochemical cells with (b) Ni-YSZ and (c) Ni-GDC working electrodes. In both cells, Pt counter and reference electrodes with identical geometry were used. 
difference between the high frequency and low frequency intercepts represents the electrode polarization resistance $\left(R_{\mathrm{p}}\right)$. The $R_{\mathrm{Ohm}}$ includes both electronic and ionic resistances, while $R_{\mathrm{p}}$ reflects the reaction kinetics typically influenced by electrochemical, gas diffusion, and conversion resistances. It can be seen that in case of Ni-YSZ electrode (Figure 7b) the $R_{\mathrm{Ohm}}$ increases about $0.7 \mathrm{Ohm} \mathrm{\textrm {cm } ^ { 2 }}$ when $20 \%$ of $\mathrm{O}_{2}$ is added to the $\mathrm{H}_{2} \mathrm{O} / \mathrm{H}_{2}$ flow. This suggests lower electronic and ionic conductance of the electrochemical cell after oxidation. In addition, $\mathrm{O}_{2}$ induces an increase of $1.1 \mathrm{Ohm} \mathrm{cm}^{2}$ at $\mathrm{R}_{\mathrm{p}}$ which can be assigned to the deterioration of the reaction kinetics.

With respect to the Ni-GDC electrode, oxidation of nickel

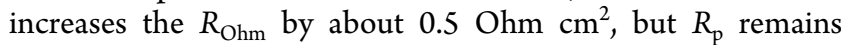
practically stable and is independent of nickel oxidation state. This result signifies that surface $\mathrm{NiO}$ formation modifies the conductance of the Ni-GDC electrode but, contrary to the NiYSZ, does not influence the reaction kinetics. Since apart of the cathode electrode, both cells have the same configuration, it is reasonable to assume that the surface oxidation state of nickel affects the electrical conduction of both cermet electrodes but is not a crucial factor of the electrocatalytic activity of Ni-GDC, probably due to a compensation brought by the charge change in the $\mathrm{Ce}^{4+} / \mathrm{Ce}^{3+}$ couple.

\section{DISCUSSION}

The above-described results suggest that the cathode surface chemical state is a crucial element of the SOEC electrochemical performance during steam electrolysis. The key processes taking place during steam electrolysis over the two cermet electrodes under reduced and partially oxidized conditions are schematically illustrated in Figure 8. Nickel

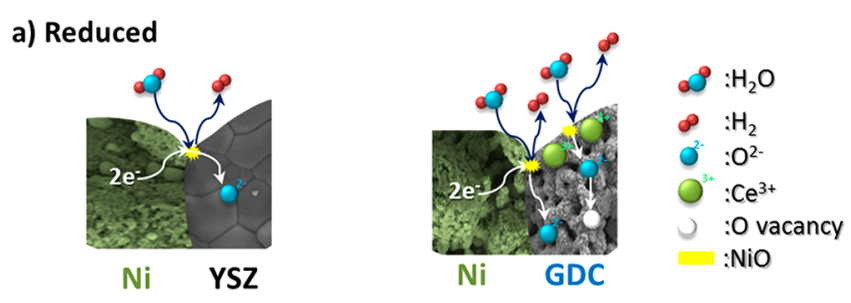

b) Partially oxidized
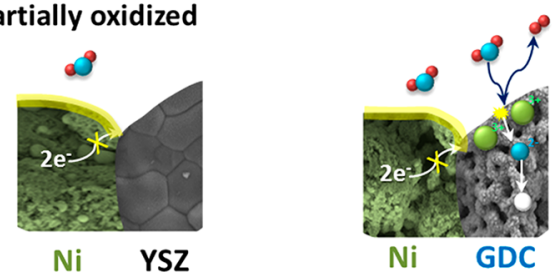

Figure 8. Simplified schematic illustration of steam electrolysis pathways over $\mathrm{Ni} / \mathrm{YSZ}$ and $\mathrm{Ni} / \mathrm{GDC}$ electrode surfaces in (a) reduced and (b) partially oxidized states. The specific sites where electrochemical reaction takes place are not shown in this figure.

oxidation is a known cause of cell deactivation, due to the lower $\mathrm{NiO}$ electrical conductivity and mechanical problems caused by volume expansion, but the specific effect of nickel surface oxidation on the $n m$-scale is revealed here for the first time. Previous $\mathrm{H}_{2}$ electroxidation studies over GDC-based electrodes proposed that the reaction is predominately taking place at the ceria/gas $2 \mathrm{~PB}$ and in a much lesser extent on the oxide/metal/gas 3PB. ${ }^{9}$ GDC, as an MIEC material, is able to conduct both oxygen ions and electrons. As a result, the electrocatalytically active reaction sites are extended to the entire GDC/gas interface. However, as mentioned above, the performance of the cell is not only a factor of the electrocatalytic activity but also of the electrical losses of the cell, which are reflected by the electrical conductance. Here we provide direct evidence that a few $\mathrm{nm}$ thick layer of $\mathrm{NiO}$ over metallic Ni particles of the Ni-GDC cermet has a small, but not negligible, effect on the electrical performance. This is consistent with the higher electronic conductivity of metallic nickel as compared to ceria, which is suppressed upon nickel oxidation influencing the cathode conductance.

Another remarkable result of this study is that small changes of ceria surface oxidation state in the GDC parts may notably influence the cell overpotential. Despite the fact that previous studies have shown that ceria is maintained in a mixed $\mathrm{Ce}^{3+} /$ $\mathrm{Ce}^{4+}$ state during electrolysis conditions, ${ }^{16,50}$ this is the first time that the GDC valence state is directly correlated to the electrolysis performance of Ni-GDC. In particular, we found that reduced surface $\mathrm{Ce}^{3+}$ sites are beneficial for the cell performance. This result is not yet fully understood but it is most probably related to the increase of the concentration of oxygen vacancies and polarons $\left(\mathrm{Ce}^{3+}\right)$ accompanying the reduction of GDC, which act as new electrochemical reaction sites promoting the activity of the electrode, ${ }^{51}$ balancing the negative effect of the $\mathrm{Ni}$ oxidation.

The positive effect of $\mathrm{Ce}^{3+}$ can be also anticipated based on our previous findings on methane electroxidation over $\mathrm{Ni}$ GDC, ${ }^{28}$ which demonstrated that reduced surface ceria sites $\left(\mathrm{Ce}^{3+}\right)$ are optimal for high fuel cell currents. Therefore, it seems likely that reduction of GDC is a critical general characteristic related with the performance of GDC electrodes. Of course, one has to keep in mind that the valence state is determined by the reaction conditions (mixture composition, temperature, and cell current), ${ }^{40,50}$ which will define the oxidation state of GDC under reaction equilibrium. However, our results propose that the enhancement of the GDC reducibility might be an efficient strategy to improve the performance of Ni-GDC based SOEC cells.

The reducibility of both doped and undoped ceria might be enhanced by controlling the characteristics of the sample $\mathrm{e}^{52,53}$ and references therein. In particular the number and type of defects, the population of the grain boundaries and the particle size, are known factors influencing the reduction of cerium oxide. ${ }^{52-54}$ In the case of doped ceria, literature reports are not conclusive regarding the effect of dopant type and concentration for the ceria reducibility. For example, some studies concluded that doping will markedly increase the reducibility of ceria as compared to the pure phase, ${ }^{55}$ while others found that dopants either do not affect, or even hinder, the reducibility of ceria. ${ }^{56,57}$ Nevertheless in an eventual attempt to produce electrodes with enhanced ceria reducibility one should also take into account the fact that reduction of ceria in the bulk will increase its electronic conductivity inducing unwanted leakage current, which if present decreases the overall cell efficiency. Therefore, in an ideal case the surface of ceria electrode should be able to reduce easily to $\mathrm{Ce}^{3+}$ to enhance electrocatalytic activity, while in the bulk the GDC composition should remain unaffected so as to maintain the mechanical and electrical properties of GDC.

\section{CONCLUSIONS}

The relationship between the cell performance and the cathode surface oxidation state for $\mathrm{Ni}-\mathrm{YSZ}$ and $\mathrm{Ni}-\mathrm{GDC}$ cermet 
electrodes during steam electrolysis was analyzed. A few nanometer thick $\mathrm{NiO}$ layer on Ni-YSZ electrode was found to increase significantly the overpotential for electrolysis reaction, but in the case of Ni-GDC its effect was minor. The surface of YSZ at the Ni-YSZ cermet was chemically stable under all conditions, whereas that of GDC was modified both by the pretreatment and by the electrochemical operation itself. A strong evidence is provided about the influence of the GDC surface oxidation state upon the cathode overpotential during electrolysis and in particular improvement of the performance with the degree of GDC surface reduction. Overall, throughout this study we demonstrated that small, reversible modifications on the outer few nanometers of the cathode electrodes might have a major influence on the cell electrochemical performance during steam electrolysis.

\section{ASSOCIATED CONTENT}

\section{S Supporting Information}

The Supporting Information is available free of charge on the ACS Publications website at DOI: 10.1021/acsaem.9b00779.

NAP-XPS spectra of the Pt working electrode under $\mathrm{H}_{2}$, polarization in $\mathrm{H}_{2} \mathrm{O} / \mathrm{H}_{2}$ mixture and $\mathrm{O}_{2}$, investigation of the effect of $\mathrm{O}_{2}$ addition in $\mathrm{H}_{2} \mathrm{O} / \mathrm{H}_{2}$ mixture, to the overpotential using symmetric $\mathrm{Pt} / \mathrm{YSZ} / \mathrm{Pt}$ cells, $\mathrm{Zr} 3 \mathrm{~d}$ NAP-XPS spectra of the Ni-YSZ cathode electrode under various conditions, analysis of the Ce M-edge NEXAFS spectrum of Ni-GDC electrode subtracting the two spectra after proper intensity normalization, comparison of the Ce $3 \mathrm{~d}$ and Ni 2p NAP-XPS spectra recorded in $\mathrm{H}_{2} \mathrm{O} / \mathrm{H}_{2}$ before the current application (O.C.) and after $95 \mathrm{~min}$ in electrolysis conditions, and evolution of the $\mathrm{Ni} 2 \mathrm{p} / \mathrm{Ce} 3 \mathrm{~d}$ peak areas ratio as a function of time for $\mathrm{Ni}-\mathrm{GDC}$ under steam electrolysis conditions (PDF)

\section{AUTHOR INFORMATION}

\section{Corresponding Author}

*Email: spiros.zafeiratos@unistra.fr.

ORCID 웅

Wen Luo: 0000-0003-4250-6168

Spyridon Zafeiratos: 0000-0001-8165-2585

\section{Notes}

The authors declare no competing financial interest.

\section{ACKNOWLEDGMENTS}

The research leading to these results has received funding from the Fuel Cells and Hydrogen 2 Joint Undertaking under the project SElySOs with grant agreement no. 671481. This Joint Undertaking receives support from the European Union's Horizon 2020 research and innovation programme and Greece, Germany, Czech Republic, France, and Norway. W.L. acknowledges the financial support from Swiss National Science Foundation (Ambizione Project PZ00P2_179989). We thank Prof. R. Schlögl and Dr. S. Neophytides for their useful and constructive comments, as well as Dr. T. Dintzer for his help collecting the SEM images. Finally, we acknowledge HZB for the allocation of synchrotron radiation beamtime.

\section{REFERENCES}

(1) Abbasi, T.; Abbasi, S. A. 'Renewable' Hydrogen: Prospects and Challenges. Renewable Sustainable Energy Rev. 2011, 15, 3034-3040.
(2) Chi, J.; Yu, H. Water Electrolysis Based on Renewable Energy for Hydrogen Production. Chin. J. Catal. 2018, 39, 390-394.

(3) Wang, M.; Wang, Z.; Gong, X.; Guo, Z. The Intensification Technologies to Water Electrolysis for Hydrogen Production - A Review. Renewable Sustainable Energy Rev. 2014, 29, 573-588.

(4) Hansen, J. B. Solid Oxide Electrolysis - a Key Enabling Technology for Sustainable Energy Scenarios. Faraday Discuss. 2015, $182,9-48$.

(5) Nguyen, V. N.; Fang, Q.; Packbier, U.; Blum, L. Long-Term Tests of a Jülich Planar Short Stack with Reversible Solid Oxide Cells in Both Fuel Cell and Electrolysis Modes. Int. J. Hydrogen Energy 2013, 38, 4281-4290.

(6) Ebbesen, S. D.; Jensen, S. H.; Hauch, A.; Mogensen, M. B. High Temperature Electrolysis in Alkaline Cells, Solid Proton Conducting Cells, and Solid Oxide Cells. Chem. Rev. 2014, 114, 10697-10734.

(7) Lay-Grindler, E.; Laurencin, J.; Villanova, J.; Cloetens, P.; Bleuet, P.; Mansuy, A.; Mougin, J.; Delette, G. Degradation Study by 3D Reconstruction of a Nickel-Yttria Stabilized Zirconia Cathode after High Temperature Steam Electrolysis Operation. J. Power Sources 2014, 269, 927-936.

(8) Gu, X. K.; Nikolla, E. Fundamental Insights into HighTemperature Water Electrolysis Using Ni-Based Electrocatalysts. J. Phys. Chem. C 2015, 119, 26980-26988.

(9) Chueh, W. C.; Hao, Y.; Jung, W.; Haile, S. M. High Electrochemical Activity of the Oxide Phase in Model Ceria-Pt and Ceria-Ni Composite Anodes. Nat. Mater. 2012, 11, 155-161.

(10) Chen, K.; Jiang, S. P. Review-Materials Degradation of Solid Oxide Electrolysis Cells. J. Electrochem. Soc. 2016, 163, F3070-F3083.

(11) Hoerlein, M. P.; Riegraf, M.; Costa, R.; Schiller, G.; Friedrich, K. A. A Parameter Study of Solid Oxide Electrolysis Cell Degradation: Microstructural Changes of the Fuel Electrode. Electrochim. Acta 2018, 276, 162-175.

(12) Al Daroukh, M.; Tietz, F.; Sebold, D.; Buchkremer, H. P. PostTest Analysis of Electrode-Supported Solid Oxide Electrolyser Cells. Ionics 2015, 21, 1039-1043.

(13) Schmidt, M. S.; Vels Hansen, K.; Norrman, K.; Mogensen, M. Three-Phase-Boundary Dynamics at the Ni/ScYSZ Interface. Solid State Ionics 2009, 180, 431-438.

(14) Futamura, S.; Tachikawa, Y.; Matsuda, J.; Lyth, S. M.; Shiratori, Y.; Taniguchi, S.; Sasaki, K. Alternative Ni-Impregnated Mixed IonicElectronic Conducting Anode for SOFC Operation at High Fuel Utilization. J. Electrochem. Soc. 2017, 164, F3055-F3063.

(15) Pihlatie, M.; Ramos, T.; Kaiser, A. Testing and Improving the Redox Stability of Ni-Based Solid Oxide Fuel Cells. J. Power Sources 2009, 193, 322-330.

(16) Papaefthimiou, V.; Niakolas, D. K. D. K.; Paloukis, F.; Teschner, D.; Knop-Gericke, A.; Haevecker, M.; Zafeiratos, S. Operando Observation of Nickel/Ceria Electrode Surfaces during Intermediate Temperature Steam Electrolysis. J. Catal. 2017, 352, $305-313$

(17) Shishkin, M.; Ziegler, T. Direct Modeling of the Electrochemistry in the Three-Phase Boundary of Solid Oxide Fuel Cell Anodes by Density Functional Theory: A Critical Overview. Phys. Chem. Chem. Phys. 2014, 16, 1798-1808.

(18) Schefold, J.; Brisse, A.; Poepke, H. 23,000 h Steam Electrolysis with an Electrolyte Supported Solid Oxide Cell. Int. J. Hydrogen Energy 2017, 42, 13415-13426.

(19) Chen, Y.; Yoo, S.; Li, X.; Ding, D.; Pei, K.; Chen, D.; Ding, Y.; Zhao, B.; Murphy, R.; deGlee, B.; Liu, J.; Liu, M. An Effective Strategy to Enhancing Tolerance to Contaminants Poisoning of Solid Oxide Fuel Cell Cathodes. Nano Energy 2018, 47, 474-480.

(20) Opitz, A. K.; Nenning, A.; Rameshan, C.; Kubicek, M.; Götsch, T.; Blume, R.; Hävecker, M.; Knop-Gericke, A.; Rupprechter, G.; Klötzer, B.; Fleig, J. Surface Chemistry of Perovskite-Type Electrodes During High Temperature $\mathrm{CO}_{2}$ Electrolysis Investigated by Operando Photoelectron Spectroscopy. ACS Appl. Mater. Interfaces 2017, 9, 35847-35860.

(21) Bozzini, B.; Amati, M.; Bocchetta, P.; Dal Zilio, S.; KnopGericke, A.; Vesselli, E.; Kiskinova, M. An in Situ Near-Ambient 
Pressure X-Ray Photoelectron Spectroscopy Study of Mn Polarised Anodically in a Cell with Solid Oxide Electrolyte. Electrochim. Acta 2015, 174, 532-541.

(22) Nakamura, T.; Oike, R.; Kimura, Y.; Tamenori, Y.; Kawada, T.; Amezawa, K. Operando Soft X-Ray Absorption Spectroscopic Study on a Solid Oxide Fuel Cell Cathode during Electrochemical Oxygen Reduction. ChemSusChem 2017, 10, 2008-2014.

(23) Geller, A.; Pomfret, M.; Steinhurst, D. A.; Yu, Y.; Liu, Z.; Owrutsky, J. C.; Eichhorn, B. W. Operando Tracking of Electrochemical Activity in Solid Oxide Electrochemical Cells by Using NearInfrared Imaging. ChemElectroChem 2015, 2, 1527-1534.

(24) Gopal, C. B.; Gabaly, F. El; McDaniel, A. H.; Chueh, W. C. Origin and Tunability of Unusually Large Surface Capacitance in Doped Cerium Oxide Studied by Ambient-Pressure X-Ray Photoelectron Spectroscopy. Adv. Mater. 2016, 28, 4692-4697.

(25) Nurk, G.; Kooser, K.; Urpelainen, S.; Käämbre, T.; Joost, U.; Kodu, M.; Kivi, I.; Kanarbik, R.; Kukk, E.; Lust, E. Near Ambient Pressure X-Ray Photoelectron - and Impedance Spectroscopy Study of NiO - Ce0.9Gd0.1O2- $\delta$ Anode Reduction Using a Novel DualChamber Spectroelectrochemical Cell. J. Power Sources 2018, 378, 589-596.

(26) Korjus, O.; Aruväli, J.; Kivi, I.; Kodu, M.; Lust, E.; Nurk, G. Simultaneous Operando Characterization of Crystallographic and Electrochemical Properties of $\mathrm{Ni}-\mathrm{Ce}_{0.9} \mathrm{Gd}_{0.1} \mathrm{O}_{2-\delta}$ Solid Oxide Fuel Cell Anode. J. Electrochem. Soc. 2018, 165, F1043-F1050.

(27) Opitz, A. K.; Rameshan, C.; Kubicek, M.; Rupp, G. M.; Nenning, A.; Götsch, T.; Blume, R.; Hävecker, M.; Knop-Gericke, A.; Rupprechter, G.; Klötzer, B.; Fleig, J. The Chemical Evolution of the $\mathrm{La} 0.6 \mathrm{Sr} 0.4 \mathrm{CoO} 3-\delta$ Surface Under SOFC Operating Conditions and Its Implications for Electrochemical Oxygen Exchange Activity. Top. Catal. 2018, 61, 2129-2141.

(28) Papaefthimiou, V.; Shishkin, M.; Niakolas, D. K.; Athanasiou, M.; Law, Y. T.; Arrigo, R.; Teschner, D.; Hävecker, M.; KnopGericke, A.; Schlögl, R.; Ziegler, T.; Neophytides, S. G.; Zafeiratos, S. On the Active Surface State of Nickel-Ceria Solid Oxide Fuel Cell Anodes during Methane Electrooxidation. Adv. Energy Mater. 2013, 3, 762-769.

(29) Paloukis, F.; Papazisi, K. M.; Dintzer, T.; Papaefthimiou, V.; Saveleva, V. A.; Balomenou, S. P.; Tsiplakides, D.; Bournel, F.; Gallet, J. J.; Zafeiratos, S. Insights into the Surface Reactivity of Cermet and Perovskite Electrodes in Oxidizing, Reducing, and Humid Environments. ACS Appl. Mater. Interfaces 2017, 9, 25265-25277.

(30) Niakolas, D. K.; Ouweltjes, J. P.; Rietveld, G.; Dracopoulos, V.; Neophytides, S. G. Au-Doped Ni/GDC as a New Anode for SOFCs Operating under Rich $\mathrm{CH} 4$ Internal Steam Reforming. Int. J. Hydrogen Energy 2010, 35, 7898-7904.

(31) Kim-Lohsoontorn, P.; Kim, Y. M.; Laosiripojana, N.; Bae, J. Gadolinium Doped Ceria-Impregnated Nickel-Yttria Stabilised Zirconia Cathode for Solid Oxide Electrolysis Cell. Int. J. Hydrogen Energy 2011, 36, 9420-9427.

(32) Derafa, W.; Paloukis, F.; Mewafy, B.; Baaziz, W.; Ersen, O.; Petit, C.; Corbel, G.; Zafeiratos, S. Synthesis and Characterization of Nickel-Doped Ceria Nanoparticles with Improved Surface Reducibility. RSC Adv. 2018, 8, 40712-40719.

(33) Knop-Gericke, A.; Kleimenov, E.; Hävecker, M.; Blume, R.; Teschner, D.; Zafeiratos, S.; Schlögl, R.; Bukhtiyarov, V. I.; Kaichev, V. V.; Prosvirin, I. P.; Nizovskii, A. I.; Bluhm, H.; Barinov, A.; Dudin, P.; Kiskinova, M. Chapter 4 X-Ray Photoelectron Spectroscopy for Investigation of Heterogeneous Catalytic Processes. Adv. Catal. 2009, 52, 213-272.

(34) Powell, C. J.; Jablonski, A. Progress in Quantitative Surface Analysis by X-Ray Photoelectron Spectroscopy: Current Status and Perspectives. J. Electron Spectrosc. Relat. Phenom. 2010, 178-179, 331-346.

(35) Maher, R. C.; Shearing, P. R.; Brightman, E.; Brett, D. J. L.; Brandon, N. P.; Cohen, L. F. Reduction Dynamics of Doped Ceria, Nickel Oxide, and Cermet Composites Probed Using in Situ Raman Spectroscopy. Adv. Sci. 2016, 3, 1500146.
(36) Hansen, K. V.; Jacobsen, T.; Thyden, K.; Wu, Y.; Mogensen, M. B. In Situ Surface Reduction of a NiO-YSZ-Alumina Composite Using Scanning Probe Microscopy. J. Solid State Electrochem. 2014, 18, 1869-1878.

(37) Laurencin, J.; Roche, V.; Jaboutian, C.; Kieffer, I.; Mougin, J.; Steil, M. C. Ni-8YSZ Cermet Re-Oxidation of Anode Supported Solid Oxide Fuel Cell: From Kinetics Measurements to Mechanical Damage Prediction. Int. J. Hydrogen Energy 2012, 37, 12557-12573.

(38) Payne, B. P.; Biesinger, M. C.; McIntyre, N. S. The Study of Polycrystalline Nickel Metal Oxidation by Water Vapour. J. Electron Spectrosc. Relat. Phenom. 2009, 175, 55-65.

(39) Zafeiratos, S.; Kennou, S. The Interaction of Oxygen with Ultrathin Ni Deposits on Yttria-Stabilized ZrO2( $\left(\begin{array}{lll}1 & 0 & 0\end{array}\right)$. Surf. Sci. 2001, 482-485, 266-271.

(40) Papaefthimiou, V.; Niakolas, D. K.; Paloukis, F.; Dintzer, T.; Zafeiratos, S. Is Steam an Oxidant or a Reductant for Nickel/DopedCeria Cermets? ChemPhysChem 2017, 18, 164-170.

(41) Peck, M. A.; Langell, M. A. Comparison of Nanoscaled and Bulk NiO Structural and Environmental Characteristics by XRD, XAFS, and XPS. Chem. Mater. 2012, 24, 4483-4490.

(42) Payne, B. P.; Grosvenor, A. P.; Biesinger, M. C.; Kobe, B. A.; McIntyre, N. S. Structure and Growth of Oxides on Polycrystalline Nickel Surfaces. Surf. Interface Anal. 2007, 39, 582-592.

(43) Cornish, A.; Eralp, T.; Shavorskiy, A.; Bennett, R. A.; Held, G.; Cavill, S. A.; Potenza, A.; Marchetto, H.; Dhesi, S. S. Oxidation of Polycrystalline Ni Studied by Spectromicroscopy: Phase Separation in the Early Stages of Crystallite Growth. Phys. Rev. B: Condens. Matter Mater. Phys. 2010, 81, 085403.

(44) De Jesús, J. C.; Pereira, P.; Carrazza, J.; Zaera, F. Influence of Argon Ion Bombardment on the Oxidation of Nickel Surfaces. Surf. Sci. 1996, 369, 217-230.

(45) Paloukis, F.; Papazisi, K. M.; Balomenou, S. P.; Tsiplakides, D.; Bournel, F.; Gallet, J. J.; Zafeiratos, S. In Situ X-Ray Photoelectron Spectroscopy Study of Complex Oxides under Gas and Vacuum Environments. Appl. Surf. Sci. 2017, 423, 1176-1181.

(46) Ladas, S.; Kennou, S.; Bebelis, S.; Vayenas, C. G. Origin of Non-Faradaic Electrochemical Modification of Catalytic Activity. J. Phys. Chem. 1993, 97, 8845-8848.

(47) El Gabaly, F.; Grass, M.; McDaniel, A. H.; Farrow, R. L.; Linne, M. A.; Hussain, Z.; Bluhm, H.; Liu, Z.; McCarty, K. F. Measuring Individual Overpotentials in an Operating Solid-Oxide Electrochemical Cell. Phys. Chem. Chem. Phys. 2010, 12, 12138-12145.

(48) Zhang, C.; Yu, Y.; Grass, M. E.; Dejoie, C.; Ding, W.; Gaskell, K.; Jabeen, N.; Hong, Y. P.; Shavorskiy, A.; Bluhm, H.; Li, W. X.; Jackson, G. S.; Hussain, Z.; Liu, Z.; Eichhorn, B. W. Mechanistic Studies of Water Electrolysis and Hydrogen Electro-Oxidation on High Temperature Ceria-Based Solid Oxide Electrochemical Cells. J. Am. Chem. Soc. 2013, 135, 11572-11579.

(49) Ioannidou, E.; Neofytidis, C.; Sygellou, L.; Niakolas, D. K. AuDoped Ni/GDC as an Improved Cathode Electrocatalyst for $\mathrm{H} 2 \mathrm{O}$ Electrolysis in SOECs. Appl. Catal., B 2018, 236, 253-264.

(50) Zhang, C.; Grass, M. E.; McDaniel, A. H.; DeCaluwe, S. C.; Gabaly, F. E.; Liu, Z.; McCarty, K. F.; Farrow, R. L.; Linne, M. A.; Hussain, Z.; Jackson, G. S.; Bluhm, H.; Eichhorn, B. W. Measuring Fundamental Properties in Operating Solid Oxide Electrochemical Cells by Using in Situ X-Ray Photoelectron Spectroscopy. Nat. Mater. 2010, 9, 944-949.

(51) Graves, C.; Chatzichristodoulou, C.; Mogensen, M. B. Kinetics of $\mathrm{CO} / \mathrm{CO}_{2}$ and $\mathrm{H}_{2} / \mathrm{H}_{2} \mathrm{O}$ Reactions at Ni-Based and Ceria-Based Solid-Oxide-Cell Electrodes. Faraday Discuss. 2015, 182, 75-95.

(52) Montini, T.; Melchionna, M.; Monai, M.; Fornasiero, P. Fundamentals and Catalytic Applications of $\mathrm{CeO} 2$-Based Materials. Chem. Rev. 2016, 116, 5987-6041.

(53) Mogensen, M.; Sammes, N. M.; Tompsett, G. A. Physical, Chemical and Electrochemical Properties of Pure and Doped Ceria. Solid State Ionics 2000, 129, 63-94.

(54) Soykal, I. I.; Sohn, H.; Singh, D.; Miller, J. T.; Ozkan, U. S. Reduction Characteristics of Ceria under Ethanol Steam Reforming Conditions: Effect of the Particle Size. ACS Catal. 2014, 4, 585-592. 
(55) Vecchietti, J.; Collins, S.; Xu, W.; Barrio, L.; Stacchiola, D.; Calatayud, M.; Tielens, F.; Delgado, J. J.; Bonivardi, A. Surface Reduction Mechanism of Cerium-Gallium Mixed Oxides with Enhanced Redox Properties. J. Phys. Chem. C 2013, 117, 8822-8831. (56) Lucid, A. K.; Keating, P. R. L.; Allen, J. P.; Watson, G. W. Structure and Reducibility of $\mathrm{CeO} 2$ Doped with Trivalent Cations. J. Phys. Chem. C 2016, 120, 23430-23440.

(57) Zając, W.; Molenda, J. Properties of Doped Ceria Solid Electrolytes in Reducing Atmospheres. Solid State Ionics 2011, 192, 163-167. 